\title{
Aetiology and Pathogenesis of Trigeminal Neuralgia: a Comprehensive Review
}

\author{
Gintautas Sabalys ${ }^{1}$, Gintaras Juodzbalys ${ }^{1}$, Hom-Lay Wang ${ }^{2}$ \\ ${ }^{1}$ Department of Maxillofacial Surgery, Lithuanian University of Health Sciences, Kaunas, Lithuania. \\ ${ }^{2}$ Department of Periodontics and Oral Medicine, School of Dentistry, University of Michigan, Ann Arbor, Michigan, USA.
}

\author{
Corresponding Author: \\ Gintaras Juodzbalys \\ Vainiku 12 \\ LT- 46383, Kaunas \\ Lithuania \\ Tel/Fax: +370 37297055 or +37037323153 \\ E-mail address: gintaras@stilusoptimus.1t
}

\begin{abstract}
Objectives: The aim of present paper was to discuss issues related to trigeminal neuralgia with strong emphasis on the aetiology and pathogenesis of this problem.

Material and Methods: An electronic search of 5 databases (1965 - Oct 2012) and a hand search of peer-reviewed journals for relevant articles were performed. In addition, experience acquired from treating 3263 patients in the Department of Maxillofacial Surgery, Lithuanian University of Health Sciences, were also summarized.

Results: Generally, aetiological factors can be classified into 3 most popular theories that were based on: 1) Related to other disease, 2) Direct injury to the trigeminal nerve, and 3) Propagates the polyetiologic origin of the disease. In addition, two pathogenesis mechanisms of trigeminal neuralgia were proposed. First: the peripheral pathogenetic mechanism that is often induced by progressive dystrophy around the peripheral branches of the trigeminal nerve. Second, central pathogenetic mechanism which often triggered by peripheral pathogen that causes long-lasting afferent impulsation and the formation of a stable pathologic paroxysmal type irritation focus on the central nerve system (CNS).

Conclusions: Patients with susceptive trigeminal neuralgia should be examined carefully by specialists who have expertise in assessing and diagnosing of possible pathological processes and be able to eliminate the contributing factors so the trigeminal neuralgia can be properly managed.
\end{abstract}

Keywords: trigeminal neuralgia; trigeminal ganglion; trigeminal nerve; trigeminal nuclei.

Accepted for publication: 29 December 2012.

To cite this article:

Sabalys G, Juodzbalys G, Wang HL. Aetiology and Pathogenesis of Trigeminal Neuralgia: a Comprehensive Review.

URL: http://www.ejomr.org/JOMR/archives/2012/4/e2/v3n4e2ht.pdf

doi: $10.5037 /$ jomr.2012.3402 


\section{INTRODUCTION}

Trigeminal neuralgia (TN) is one of the most common diseases of cranial nerves. Furthermore, it is the most frequently diagnosed form of facial pain with a prevalence of 4 per 100,000 in the general population [1]. This condition has been known since ancient times, having been described by Arateus in the first century A.D. [2]. John Locke, in 1677 identified the major clinical features of TN [3] . French physician Nicolaus Andre in 1756 gave the name "tic douloureux" because of the facial spasms that would accompany the attacks [4]. English physician John Fothergill in 1773 defined the major clinical features of TN [5]. Since that time TN has been investigated extensively by scientists and clinicians from different fields: pathophysiologists, neuromorphologists, dentists, neurologists, neurosurgeons, oculists, and psychiatrists. Unfortunately many problems associated with TN remain unresolved.

\section{MATERIAL AND METHODS}

This article reviewed the literature related to the etiologies and pathogenesis of TN. Due to enormous literature available it is impossible to review and cite all papers, hence we cited literature when appropriate. In addition, we have added our experience/views acquired from treating 3263 patients in the Department of Maxillofacial Surgery, Lithuanian University of Health Sciences.

\section{Aetiology of trigeminal neuralgia (TN)}

There are many different opinions concerning TN aetiology, however some of them are controversial and suffer from a lack of objective evidence. Such are aetiologic theories as endogenous and exogenous intoxication [6], temporomandibular joint pathology [7-9] and high position of the petrous pyramid apex of the temporal bone [10].

Currently, there are three most popular TN aetiologic theories. First theory is based on diseases-related, second is direct trauma to the nerve and the third theory propagates the polyetiologic origin of the disease (Table 1). In reality, for most patients with $\mathrm{TN}$, there is no identifiable cause [11].

Because patients suffering from $\mathrm{TN}$ often have vascular diseases such as atherosclerosis, arterial hypertonia, some authors suggested vascular theory of TN aetiology. They found morphological and functional disturbance in blood vessels supplying the peripheral [12] and central $[13,14]$ part of trigeminal nerve system (TNS). However, there is no evidence that supports direct relation of blood vessels pathology to TN. Smoliar [15] investigated blood vessels supplying trigeminal nerve for a large number of cadavers who died because of cardiovascular disease. Although, clear morphological changes were noted in the blood vessels but no TN was diagnosed. That's why we prefer to support the concept $[16,17]$ that organic or functional changes of blood vessels supplying TNS can not be the primary cause of $\mathrm{TN}$, however, they can make influence on pathogenesis of the disease.

Some authors have suggested the importance of multiple sclerosis in TN aetiology [17-26]. However, others have disputed this link because TN is reported to occur only in $0.9 \%$ to $4.5 \%$ of patients that had multiple sclerosis [2729]. Conversely, $1.7 \%$ to $15 \%$ of patients diagnosed with TN had developed of multiple sclerosis $[\underline{1}, \underline{27}, \underline{28}, \underline{30}, \underline{31}]$. This is further supported by Rusthon and Olfason [27], who examined 3880 patients with multiple sclerosis and 1735 patients with TN and found only 35 patients had both diseases. In patients with both $\mathrm{TN}$ and multiple sclerosis, TN is the first symptom of multiple sclerosis in $9 \%-14 \%$ patients $[29, \underline{30}]$. After treatment of 3263 patients with diagnosed TN in our department, we found that $46(1.4 \%)$ of patients suffered from rheumatism,

Table 1. Three most popular theories of trigeminal neuralgia aetiology

\begin{tabular}{|c|c|c|c|}
\hline \multirow{2}{*}{ Diseases related } & \multicolumn{2}{|c|}{ Direct injury to the trigeminal nerve } & \multirow{2}{*}{ Polyetiologic origin } \\
\hline & Peripheral part of TNS & Central part of TNS & \\
\hline $\begin{array}{l}\text { Vascular diseases, } \\
\text { multiple sclerosis, } \\
\text { diabetes mellitus, } \\
\text { rheumatism and } \\
\text { others. }\end{array}$ & $\begin{array}{l}\text { "Allergic hypothesis" due to } \\
\text { odontogenic inflammatory } \\
\text { diseases, otolaryngological } \\
\text { pathology, getting cold and } \\
\text { others. } \\
\text { "Compression syndrome } \\
\text { hypothesis" due to the narrowing } \\
\text { of the osseous canals, trauma. }\end{array}$ & $\begin{array}{l}\text { "Neurovascular compression hypothesis" } \\
\text { at the root entry zone due to arteriovenous } \\
\text { malformation, vestibular schwannomas, } \\
\text { meningiomas, epidermoid cysts, } \\
\text { tuberculomas, various other cysts and } \\
\text { tumours, aneurysm, vessels aggregation } \\
\text { and occlusion due to arachnoiditis and } \\
\text { others. }\end{array}$ & $\begin{array}{l}\text { All possible aetiological } \\
\text { factors that can affect TNS } \\
\text { and evoke demyelination } \\
\text { and dystrophy. }\end{array}$ \\
\hline
\end{tabular}

$\mathrm{TNS}=$ trigeminal nerve system. 
only $7(0.23 \%)$ from multiple sclerosis and $7(0.23 \%)$ from malaria. Therefore, there is insufficient evidence to support that multiple sclerosis can be a primary cause of TN.

Urban etal. [32] investigated the frequency of subclinical trigeminal and facial nerve involvement in 40 patients with diabetes mellitus (DM) and without clinical signs of cranial nerve lesions. Sixty percent of the patients had distal symmetric sensory polyneuropathy that was confirmed by nerve conduction studies. An electrophysiological study indicated that DM could often affect trigeminal nerve function. Finestone et al. [33] reported that among a series of 40 patients with TN, 19 patients (48\%) had DM. Collis et al. [34] reviewed 30 patients with typical TN and found elevated blood sugar (using glucose tolerance tests) in 10 patients. Consequently, DM can be a causative factor for TN.

One of the local aetiological TN factors discussed in the literature is the history of odontogenic inflammatory diseases. Some authors declare that a variety of odontogenic inflammatory diseases can be a cause of TN development [35-39]. In contrast, Kerr [16] deny the odontogenic origin of $\mathrm{TN}$.

There seem to be a consensus between different authors concerning the importance of the otolaryngological pathology in TN aetiology. Chronic inflammation of maxillary sinuses and other ear, nose and throat (ENT) inflammatory disorders can be a direct cause of TN development [40-43]. Consequently, $89.5 \%$ of our treated patients suffered from inflammatory diseases in the maxillofacial region or had history of inflammatory disorders of ear, nose and throat region. Most of them suffered from chronic maxillary sinusitis, periodontitis, periostitis, phlegmone, and dental cysts.

Some authors suggest that the cause of the TN can be related to the compression syndrome, and the most popular is neurovascular compression hypothesis [4456]. Neurovascular compression at the root entry zone can be evoked by an arteriovenous malformation [57-60]. A wide range of other compressive lesions can also cause TN. These include vestibular schwannomas $[\underline{61}, \underline{62}]$,

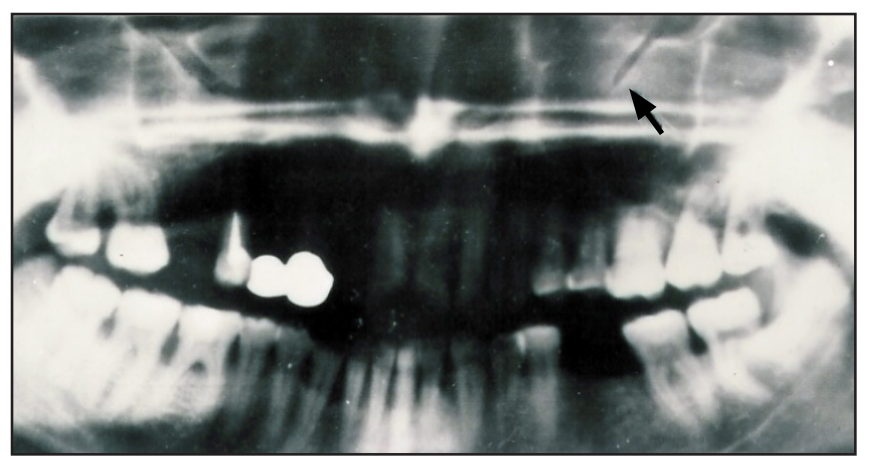

Figure 1. An orthopantomograph of a patient with infraorbital neuralgia: a narrowed left infraorbital canal (arrow). meningiomas [63-66], epidermoid cysts [67-70], tuberculomas [71-72] and various other cysts and tumours $[66,67,70,73-77]$. TN can be evoked also by presence of aneurysm $[\underline{78}, 79]$, vessels aggregation and occlusion due to arachnoiditis [80]. Compression of the trigeminal nerve root may be mediated by the tumour itself, by an interposed blood vessel or by distortion of the contents of the posterior fossa with displacement of the nerve root against a blood vessel or the skull base.

On the other hand, many patients with $\mathrm{TN}$ do not have a culprit vessel [81]. In several reported cases, the neuralgia was contralateral to the side of the mass lesion $[63,74,75]$. Furthermore, there is some evidence contrary to the neurovascular compression hypothesis. For example, in two studies on cadavers without TN, neurovascular contact was observed in $13-32 \%$ of cadavers with neurovascular compression ranging from 8 to $10 \%[42, \underline{82}]$. Similarly, in one MRI study that examined 170 trigeminal nerves in 85 non-TN patients, 79 nerves $(46 \%)$ had some point of contact with a vascular structure, 24 (14\%) had cisternae contact, $52(30 \%)$ had contact at the root entry zone, and remaining $3(2 \%)$ had an actual deformity of the root entry zone [84]. On the contrary, in non-TN patients, vascular contact with trigeminal nerve occurred only in $7 \%$ [84] and $8 \%$ [85] of cases. Although the vascular compression theory is popular, it cannot account for all phenomena associated with the TN [86].

As early as 1925, Sicard [87] proposed a hypothesis according to which TN may develop due to the narrowing of the osseous canals transmitting the corresponding nerve branches. We analyzed the maxillary $(\mathrm{n}=359)$ and mandibular $(\mathrm{n}=239)$ canals using the orthopantomograms in patients suffering from TN. The analysis revealed that $29.2 \%$ of patients had a narrowed infraorbital canal (Figure 1) and 31.4\% mandibular canal (Figure 2) transmitting the branches of the affected side of trigeminal nerve. Doppler ultrasound examination indicated reduced blood flow

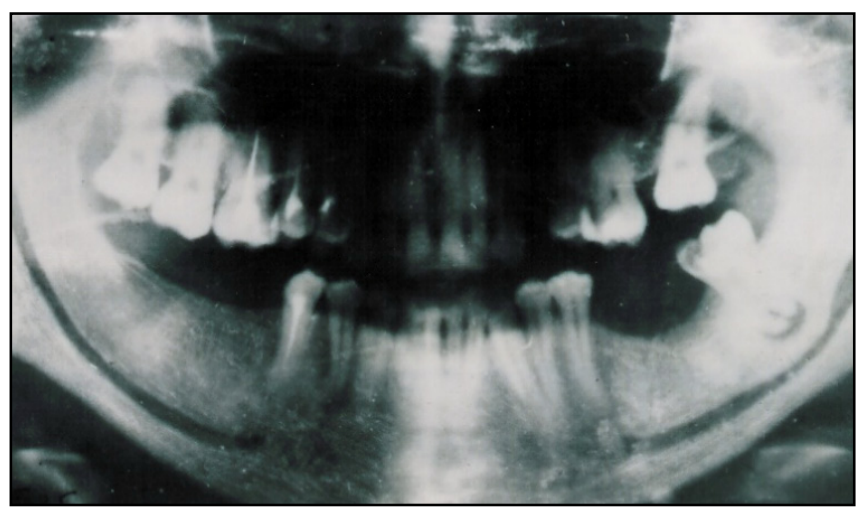

Figure 2. An orthopantomograph of a patient with a third-branch trigeminal neuralgia: a narrowed left mandibular canal in the region of a second molar. 
velocity in the infraorbital (asymmetry coefficient $=$ 2.23) and inferior alveolar (asymmetry coefficient $=$ 2.33) arteries on the affected side in comparison with intact side arteries, confirmed radiological findings and presence of compression mechanism.

"Allergic hypothesis" of TN aetiology has also been proposed [88-91]. However, there is only indirect evidence that supports allergy might cause TN. This is often due to unexpected and irregular rise of the clinical symptoms, remissions and recurrences, sensitive to the provocative endogenous and exogenous factors, and finally the increased serum levels of histamine. We noted that under the influence of various damaging factors, such as getting cold, tonsillitis, chronic rhinitis, maxillary sinusitis, and chronic inflammation existed in the maxillofacial region can trigger local immune response. As a result, the amount of $\operatorname{IgE}$ secretion increases. The degranulating mast cells release biologically active substances, such as histamine, serotonin and others, into the intercellular space. Hence, histamine release and accumulation in the trigeminal nerve during a local allergic reaction plays an important role in the pathogenesis of neuralgia [92]. Furthermore, this process is confirmed by the data of our morphologic trigeminal nerve examination and histamine levels in peripheral blood and saliva investigations [92]. Thus, microscopic immuno luminescent investigation of peripheral part of trigeminal nerve rhizotomy specimens from the TN patients revealed many degranulating mast cells and conglomerates of immune complexes of various sizes (Figure 3A). During remission, mast cells were absent in the resected nerve trunks. Many disorderly scattered granules of different size and their accumulations were found in the internal and external epineurium of the trunks (Figure 3B). At the same time we have determined an increase of histamine level in the blood and saliva during the acute period of TN. Consequently the levels of histamine in blood were:
$3.879 \pm 0.342 \mu \mathrm{mol} / 1$ (mean \pm standard deviation) and saliva $4.554 \pm 0.513 \mu \mathrm{mol} / \mathrm{l}$ were statistically significantly higher $(\mathrm{P}<0.05)$ when compared to the healthy individuals where the histamine level in the blood was $0.558 \pm 0.063 \mu \mathrm{mol} / 1$ and in saliva $0.522 \pm$ $0.001 \mu \mathrm{mol} / \mathrm{l}$. Moreover, the concentration of histamine level in the saliva of the TN patients was significantly higher $(\mathrm{P}<0.001)$ than in their blood. This fact indicates that histamine is released locally for those patients.

$\mathrm{Jia}$ and $\mathrm{Li}$ [93], explored the non-invasive methods to treat $\mathrm{TN}$ and as a result they also proposed a new hypothesis on the pathogenesis of TN - bioresonance. The bioresonance hypothesis states when the vibration frequency of a structure surrounding the trigeminal nerve becomes close to its natural frequency, the resonance of the trigeminal nerve occurs. The bioresonance can damage trigeminal nerve fibers and lead to the abnormal transmission of the impulse, which may finally result in facial pain.

Devor et al. [94] raised the ignition hypothesis of TN that is based on recent advances in the understanding of abnormal electrical behavior in injured sensory neurons and the findings from histopathologic observations obtained from patients with $\mathrm{TN}$, who are undergoing microvascular decompression surgery. According to this hypothesis, TN results from specific abnormalities of trigeminal afferent neurons in the trigeminal root or ganglion. Injury renders axons and axotomized somata hyperexcitable. The hyperexcitable afferents, in turn, give rise to pain paroxysms as a result of synchronized after discharge activity. Nonetheless, more evidences are needed to further verify this hypothesis.

\section{Pathogenesis and pathomorphology}

Pathogenesis of TN is one of the most complicated, unclear and extensively debated topics in medicine. Many theories and hypotheses concerning peripheral

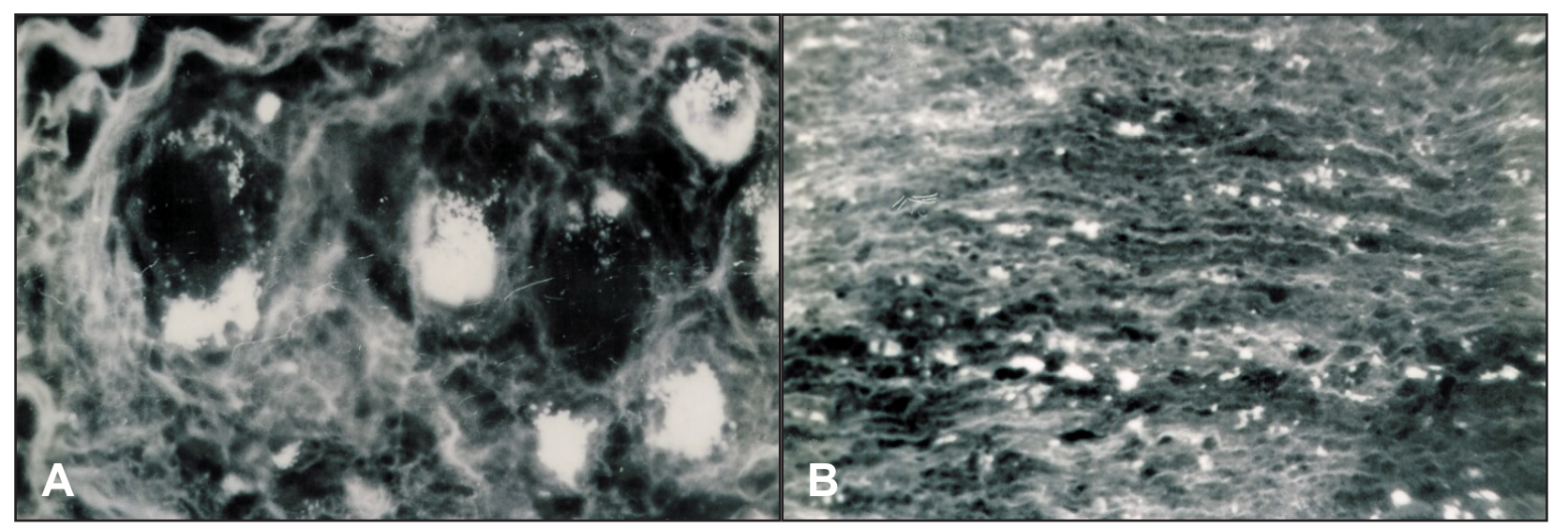

Figure 3. Fluorescent photomicrograph of an affected peripheral branch of the compromised nerve: $A=A c u t e$ stage of $\mathrm{TN}$. Mast cell degranulation. Magnification x300.

$\mathrm{B}=$ Remission period of TN. Granules of mast cells. Magnification x300. 
and central pathogenetic mechanisms existed today. At the beginning TN was characterized as functional disease because there was no evidence of organic (morphologic) changes in trigeminal nerve. However, more than 40 years ago, Kerr [16] examined histologically the rhizotomy specimens from the TN patients and found morphological nerve changes existed typical for interstitial neuritis, neural fibers demyelization, and perineural and endoneural sclerosis. For many years, the most popular theory of peripherial mechanism of the disease was "short connection" theory proposed by Dott in 1951 [103]. According to this theory, TN attack starts from demyelinated axons interconnection, spontaneous activity and ectopic impulses generation. Later published data addressing morphological changes occurred not only in peripheral branches but also in central structures of trigeminal nerve [95-98]. Central mechanisms theory assumes that TN starts due to thalamus [99], nuclei of trigeminal nerve $[100]$, encephalic trunk or cerebral cortex injury $[101,102]$. However, there is a lack of objective evidence supporting the theories of central and peripheral TN pathogenic mechanism. Furthermore, such theories are not clarifying symptoms and clinical course of the disease. More works in this area are needed.

Williams [104] was first to describe TN attack as multineuronal reflex, which involves the following structures: trigeminal and facial nerves systems, formation reticularis, diencephalon nucleus and cortex of the brain. Some researchers $[101,105]$ have indicated that afferent physiologic stimulation of trigeminal nerve receptors can induce paroxysmal excitation focus on central structures that generates efferent impulses to the peripheries. However two main questions remain unanswered: what structures are generating long prethreshold impulses from peripheries? And what central structures of the trigeminal nerve are responding by paroxysmal type discharge?
The morphological data obtained from rhizotomy specimens collected from the $212 \mathrm{TN}$ patients [89] was designed to answer the first question and to explain the peripheral pathology mechanism of the TN. The dystrophy of neural fibers is prevalent in the acute period of neuralgia. In contrast, proliferation and reparation is starting in subacute period: number of neural fibers with signs of dystrophy is decreasing and fibers with signs of regeneration increasing (Figure 4A). Connective tissue is replacing destroyed neural fibers. Consequently the conditions for nerve regeneration are worsening after each exacerbation of the disease (Figure 4B). These include but not limited to sclerotic changes of the nerve, hypoxia due to insufficient blood supply is developing and metabolic products are accumulating. Peripheral nerve branches are first affected by dystrophic changes. Nerve dystrophy is developing retrogradially and finally all peripheral branches of trigeminal nerve system are involved. This is often referred to "vicious cycle". Because the functional and anatomical connectivity between neural fibers of main trigeminal nerve branches and their surrounding sheaths and blood vessels, when one get affected, it affects the others too and vise versa. With progressing of the disease, the dystrophy is developing not only in peripheral branch of trigeminal nerve but also in intracranial nerve part. Injury of "vicious circle" and dystrophy of the TNS can be evoked by mentioned above different aetiological factors.

It was demonstrated that allergic-immune reaction of trigeminal nerve peripheral branches with expressed mast cells degranulation could be other cause of the TNS dystrophy. Biologically active agents like histamine, serotonin, heparin, bradikinine, and others are migrating into intracellular spaces during mast cells degranulation [106-107]. Mast cells degranulation evokes local immediate hyperergic reaction [108109]. This reaction starts when immunoglobulines,

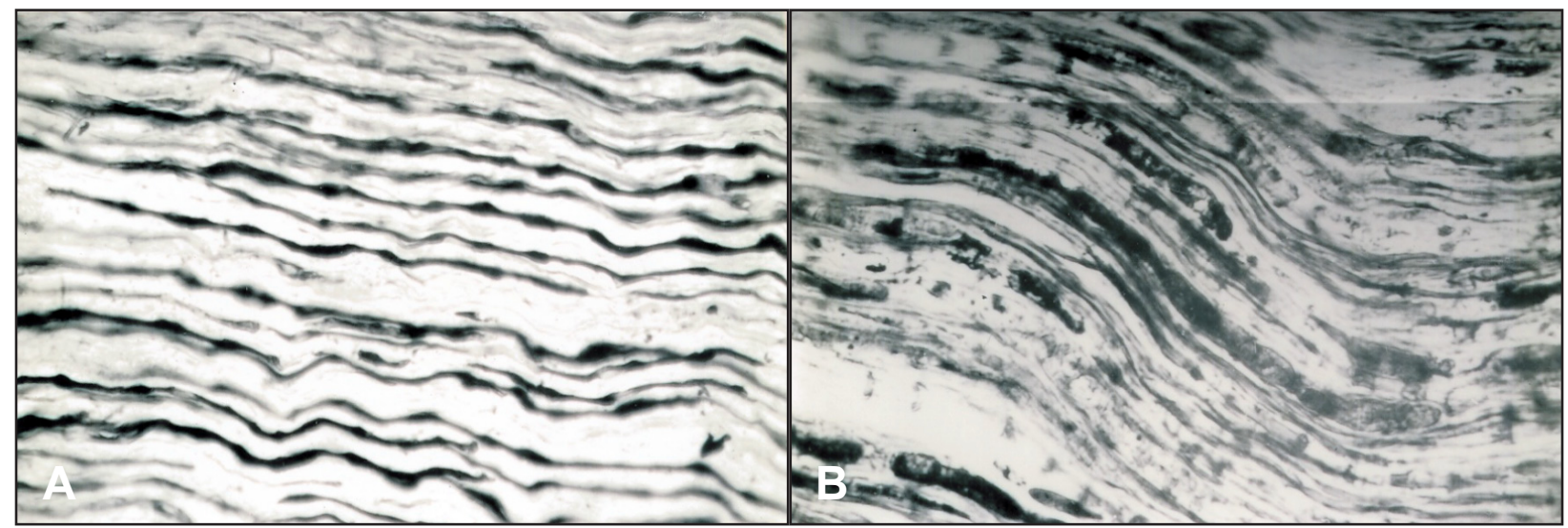

Figure 4. Illustrated an affected peripheral branch of the compromised trigeminal nerve. This sample was taken during an acute period of trigeminal neuralgia from a patient with at least three-year-long history of the TN (Bielschowsky-Gross silver impregnation; magnification x240): A = Part of thick nerve fibers with nodular thickenings; B = Vacuolisation and disintegration of nerve fibers. 
mainly $\operatorname{IgE}$, are fixing to specific receptors of mast cells [110-111]. Cells producing IgE are localized in lymphoid tissue, ears, nose, oral cavity and upper respiratory tract mucous membrane [112]. In presence of some diseases, concentration of $\operatorname{IgE}$ is increasing considerably, for example in case of ear, nose and throat inflammatory disease it increases 3 times and in nasal polyps 5 - 6 times [113]. Therefore, the amount of IgEantibodies is increasing when individual is suffering from inflammatory diseases noted in the maxillofacial region (e.g., face, nose, maxillary sinus, tonsil etc) as it was shown in case of TN (Figures 5 and 6).

Furthermore, histamine level increases significantly $(\mathrm{P}<0.05)$ in acute TN period [114]. Histamine is an active regulator of neural structures functional activity including pain reaction mediation [115]. It has been shown that TNS is chemoreceptor trigger zone of histamine [89]. This may explain why histamine released during immediate local immune reaction and accumulated in trigeminal nerve during TN pathogenesis. Neurovascular bundles of trigeminal nerve are localized in osseous canals. Hence, edema of peripheral nerves evoked by immune inflammation often results in manifestation of "tunnel syndrome". It means that the osseous canals will become narrower to compress the nerve that can lead to TN.

What we have discussed here are examples to illustrate that peripheral mechanism of TN pathogenesis. This theory is based on dystrophy of progressing TNS, which evokes long-lasting prethreshold afferent pathologic impulsion. Studies have shown that ectopic impulses can arise from demyelinated axons $[116,117]$. However, this hypothesis is not in coincidence with clinical signs of short paroxysms. Maybe, there are other pathologic mechanisms of TN, which might evoke pain paroxysms. Karlov [118] proposed the "Central pathogenesis theory" since TNS conjunction to the central structure is capable to exert inhibitory action upon the segmental and suprasegmental formations. This inhibitory action is capable to form a stable irritation focus of paroxysmal type located in the CNS. This central pathogenesis theory was confirmed further by Smith and McDonald [117]. They proved experimentally that demyelination could be the source of ectopic impulses that evokes functional disturbances and pain dominant focus formation in the segmental apparatus of brain stem and in suprasegmental brain centers. Thus, progressive dystrophy in the TNS stimulates the central pathogenesis mechanism of neuralgia. Undoubtedly, there should be appropriate conditions in the body for these pathogenetic mechanisms to manifest. Atherosclerosis and other age related alterations weaken the state of the neurohumoral barrier complex, on which the reliability of adaptive and compensatory reactions depends. Therefore, more

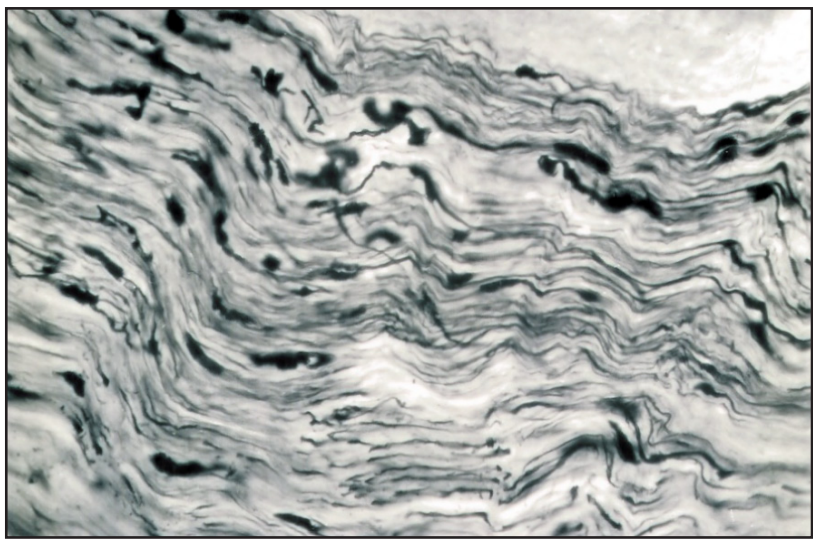

Figure 5. Pathologic regeneration shown in a specimen of an affected peripheral branch of the compromised nerve taken during a remission period of TN (Bielschowsky-Gross silver impregnation; magnification $\mathrm{x} 150$ ).

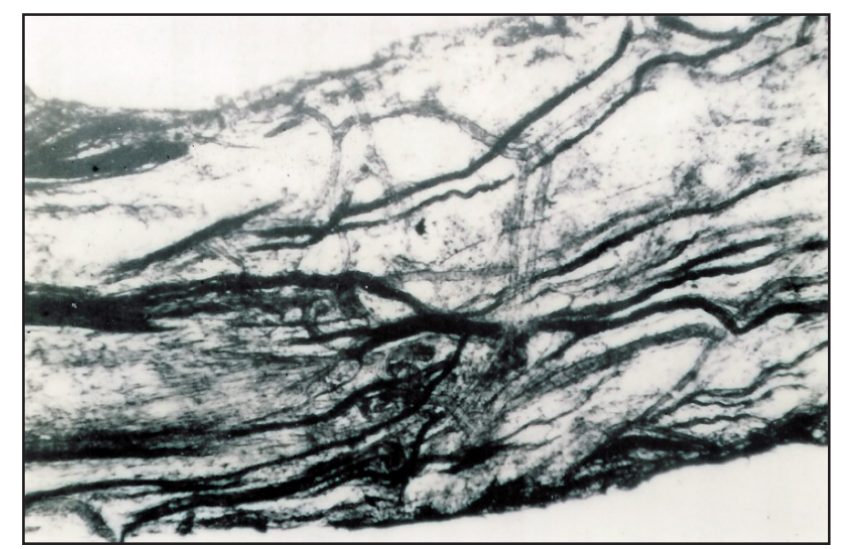

Figure 6. Increased amount of connective tissue and decreased number of nerve fibers in an affected peripheral branch of the compromised nerve. The samle was taken from a patient with a more than ten-year-long history of TN (Silver impregnation; magnification $\mathrm{x} 75$ ).

favorable conditions develop for the formation of the pathogenetic mechanisms of TN in the elderly and in older individuals affected by the local aetiologic factors. We support mechanism of TN where a long-lasting afferent pathologic impulsation from periphery is forming "focus" or "generator" in CNS which is independent of afferent impulsation. Impulses from trigger zones are passing to the main neurons of "generator" and activating them. "Generator" is activating reticulate, mesencephalon structures, limbo nuclei, limbic system, and brain cortex and finally pathologic algogenic system is forming. Figure 7 describes the two most common mechanisms of TN.

\section{CONCLUSIONS}

The peripheral pathogenetic mechanism of trigeminal neuralgia is induced by progressive dystrophy in the peripheral branches of the trigeminal nerve 


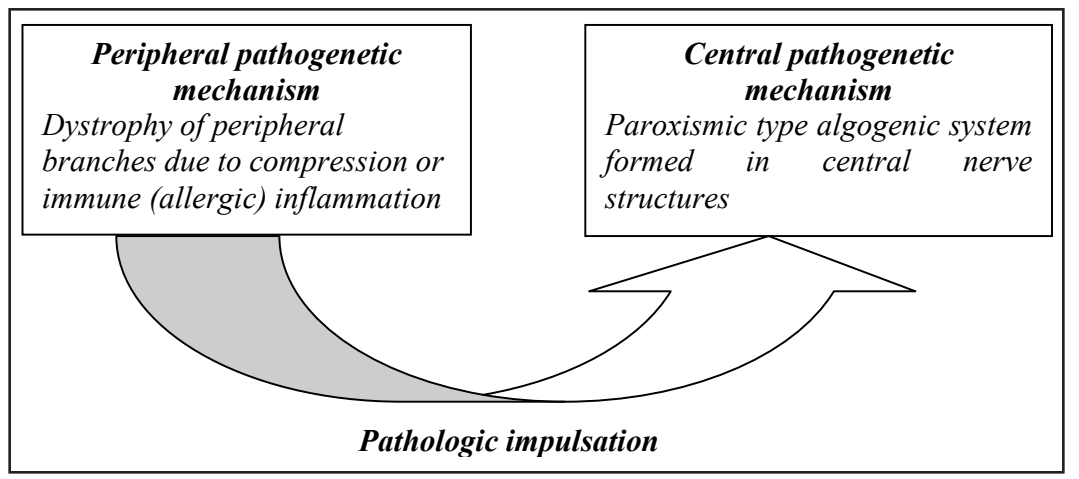

Figure 7. Pathogenetic scheme of TN.

which can be evoked by the compression syndrome (neurovascular compression due to neoplasms, narrowed bone canals and others) or allergic-immune reaction (mast cell degranulation and histamine release). This predetermines long-lasting afferent impulsation and the formation of a central pathogenetic mechanism (a stable pathologic paroxysmal type irritation focus in the central nerve system). Patients with suspective trigeminal neuralgia should be examined carefully by specialists who have expertise in assessing and diagnosing of possible pathological processes and be able to eliminate the contributing factors so the trigeminal neuralgia can be properly managed.

\section{ACKNOWLEDGMENTS AND DISCLOSURE STATEMENTS}

The authors report no conflicts of interest related to this study.

\section{REFERENCES}

1. Katusic S, Beard CM, Bergstralh E, Kurland LT. Incidence and clinical features of trigeminal neuralgia, Rochester, Minnesota, 1945-1984. Ann Neurol. 1990 Jan;27(1):89-95. [Medline: 2301931] [doi: 10.1002/ana.410270114]

2. Adams F. The extent works of Aretaeus, the Cappadocian. London: Sydenham Society; 1856. p. 350-491. URL: http://www.chlt.org/sandbox/dh/aretaeusEnglish/index.html

3. Ameli NO. Avicenna and trigeminal neuralgia. J Neurol Sci. 1965 Mar-Apr;2(2):105-7. [Medline: 4862205]
[ [doi: 10.1016/0022-510X(65)90074-2]

4. Andre NA. Observations. College et. de l'Academie Royale de Chururgie. Paris: Delaguette; 1756.

5. Fothergill J. Of a painful affection of the face. London: Medical Observations and Inquiries by a Society of Physicians in London. 1773;5. p. 129-42.

6. Bernat JL, Sullivan JK. Trigeminal neuralgia from digitalis intoxication. JAMA. 1979 Jan 12;241(2):164. [Medline: 758516] [doi: 10.1001/jama.1979.03290280044027]

7. Costen J.B. Outline of the mandibular joint syndrome. Laryngoscope. 1959 Apr;69(4):408-14. [Medline: 13655709] [doi: 10.1288/00005537-195904000-00009]

8. Scheerer WD, Hildmann H. [Ear pains by alterations of the mandibular joint (author's transl)]. Laryngol Rhinol Otol (Stuttg). 1979 Mar;58(3):259-63. German. [Medline: 439990]

9. Miller DB. The "missing link" in the origin of trigeminal neuralgia: a new theory and case report. Funct Orthod. 1999 Jan-Mar;16(1):4-6, 8, 10-3. [Medline: 10613123]

10. Smith DG, Mumford JM. Petrous angle and trigeminal neuralgia. Pain. 1980 Jun;8(3):269-77. [Medline: 7402689] [doi: 10.1016/0304-3959(80)90072-X]

11. Zakrzewska JM. Diagnosis and differential diagnosis of trigeminal neuralgia. Clin J Pain. 2002 Jan-Feb;18(1):14-21. Review. [Medline: 11803298] [doi: 10.1097/00002508-200201000-00003]

12. Marinković S, Todorović V, Gibo H, Budec M, Drndarević N, Pesić D, Joković M, Cetković M. The trigeminal vasculature pathology in patients with neuralgia. Headache. 2007 Oct;47(9):1334-9. [Medline: 17927650] [doi: 10.1111/j.1526-4610.2007.00933.x]

13. Drinnan AJ. Differential diagnosis of orofacial pain. Dent Clin North Am. 1978 Jan;22(1):73-87. [Medline: 271625]

14. Siqueira SR, Teixeira MJ, Siqueira JT. Clinical characteristics of patients with trigeminal neuralgia referred to neurosurgery. Eur J Dent. 2009 Jul;3(3):207-12. [Medline: 19756195] [FREE Full Text]

15. Smoliar E, Smoliar A, Sorkin L, Belkin V. Microcirculatory bed of the human trigeminal nerve. Anat Rec. 1998 Feb;250(2):245-9. [Medline: 9489785] [doi: 10.1002/(SICI)1097-0185(199802)250:2<245::AID-AR14>3.0.CO;2-O] 
16. Kerr FW. Pathology of trigeminal neuralgia: light and electron microscopic observations. J Neurosurg. 1967 Jan;26(1):Suppl:151-6. [Medline: 4163664]

17. Katusic S, Beard CM, Bergstralh E, Kurland LT. Incidence and clinical features of trigeminal neuralgia, Rochester, Minnesota, 1945-1984. Ann Neurol. 1990 Jan;27(1):89-95. [Medline: 230193] [doi: 10.1002/ana.410270114]

18. Brisman R. Trigeminal neuralgia and multiple sclerosis. Arch Neurol. 1987 Apr;44(4):379-81. [Medline: 3493757]

19. Hilton DA, Love S, Gradidge T, Coakham HB. Pathological findings associated with trigeminal neuralgia caused by vascular compression. Neurosurgery. 1994 Aug;35(2):299-303; discussion 303. [Medline: 7969838] [doi: 10.1227/00006123-199408000-00017]

20. Love S, Coakham HB. Trigeminal neuralgia: pathology and pathogenesis. Brain. 2001 Dec;124(Pt 12):2347-60. Review. Erratum in: Brain 2002 Mar;125(Pt 3):687. [Medline: 11701590] [doi: 10.1093/brain/124.12.2347] [FREE Full Text]

21. Rasche D, Kress B, Schwark C, Wirtz CR, Unterberg A, Tronnier VM. Treatment of trigeminal neuralgia associated with multiple sclerosis: case report. Neurology. 2004 Nov 9;63(9):1714-5. [Medline: 15534264] [doi: 10.1212/01.WNL.0000142972.12040.44]

22. Sarlani E, Grace EG, Balciunas BA, Schwartz AH. Trigeminal neuralgia in a patient with multiple sclerosis and chronic inflammatory demyelinating polyneuropathy. J Am Dent Assoc. 2005 Apr;136(4):469-76. Review. [Medline: 15884316]

23. Emril DR, Ho KY. Treatment of trigeminal neuralgia: role of radiofrequency ablation. J Pain Res. 2010 Dec 12;3:249-54. [Medline: 21311718] [doi: 10.2147/JPR.S14455] [FREE Full Text]

24. Balasundram S, Cotrufo S, Liew C. Case series: non vascular considerations in trigeminal neuralgia. Clin Oral Investig. 2012 Feb;16(1):63-8. Epub 2011 Jan 6. [Medline: 21210165] [doi: 10.1007/s00784-010-0499-2]

25. Park YS, Kim JP, Chang WS, Kim HY, Park YG, Chang JW. Gamma knife radiosurgery for idiopathic trigeminal neuralgia as primary vs. secondary treatment option. Clin Neurol Neurosurg. 2011 Jul;113(6):447-52. Epub 2011 Feb 16. [Medline: 21330049] [doi: 10.1016/j.clineuro.2011.01.006]

26. Montano N, Papacci F, Cioni B, Di Bonaventura R, Meglio M. Percutaneous balloon compression for the treatment of trigeminal neuralgia in patients with multiple sclerosis. Analysis of the potentially prognostic factors. Acta Neurochir (Wien). 2012 May;154(5):779-83. Epub 2012 Feb 22. [Medline: 22350443] [doi: 10.1007/s00701-012-1301-9]

27. Rushton JG, Olafson RA. Trigeminal neuralgia associated with multiple sclerosis: Report of 35 cases. Arch Neurol. 1965;13(4):383-6. [doi: 10.1001/archneur.1965.00470040049007]

28. White JC, Sweet WH: Pain and the Neurosurgeon. A. Forty-Year Experience. Springfield, Ill: Charles C. Thomas, 1969.

29. Hooge JP, Redekop WK. Trigeminal neuralgia in multiple sclerosis. Neurology. 1995 Jul;45(7):1294-6. [Medline: 7617185] [doi: 10.1212/WNL.45.7.1294]

30. Jensen TS, Rasmussen P, Reske-Nielsen E. Association of trigeminal neuralgia with multiple sclerosis: clinical and pathological features. Acta Neurol Scand. 1982 Mar;65(3):182-9. [Medline: 7080803] [doi: $10.1111 / \mathrm{j} .1600-0404.1982 . t b 03076 . x$ ]

31. Berk C, Constantoyannis C, Honey CR. The treatment of trigeminal neuralgia in patients with multiple sclerosis using percutaneous radiofrequency rhizotomy. Can J Neurol Sci. 2003 Aug;30(3):220-3. [Medline: 12945945]

32. Urban PP, Forst T, Lenfers M, Koehler J, Connemann BJ, Beyer J. Incidence of subclinical trigeminal and facial nerve involvement in diabetes mellitus. Electromyogr Clin Neurophysiol. 1999 Jul-Aug;39(5):267-72. [Medline: 10421997]

33. Finestone AJ, Choudhry M, Shenkin HA. Trigeminal neuralgia and diabetes mellitus. J Med Soc N J. 1970 Jun;67(6):26970. [Medline: 5269782]

34. Collis JS Jr, Wallace TW. Tic douloureux and diabetes mellitus. Cleve Clin Q. 1968 Jul;35(3):155-7. [Medline: 5747184$]$

35. Roberts AM, Person P, Chandran NB, Hori JM. Further observations on dental parameters of trigeminal and atypical facial neuralgias. Oral Surg Oral Med Oral Pathol. 1984 Aug;58(2):121-9. [Medline: 6592503] [doi: 10.1016/0030-4220(84)90123-3]

36. Grechko VE, Puzin MN. [Etiological factors in odontogenic lesions of the trigeminal nerve system]. Stomatologiia (Mosk). 1986 Mar-Apr;65(2):34-6. Russian. [Medline: 3459273]

37. Fracica F, Brickman J, LoMonaco CJ, Lin LM. Trigeminal neuralgia and endodontically treated teeth. J Endod. 1988 Jul;14(7):360-2. [Medline: 3251999] [doi: 10.1016/S0099-2399(88)80199-7]

38. Hotta TH, Bataglion A, Bataglion C, Bezzon OL. Involvement of dental occlusion and trigeminal neuralgia: a clinical report. J Prosthet Dent. 1997 Apr;77(4):343-5. [Medline: 9104707] [doi: 10.1016/S0022-3913(97)70155-0]

39. al-Gailani M, Haidar Z. Trigeminal neuralgia: an unusual case of dental origin. Odontostomatol Trop. 1987 SepDec;10(3-4):225-7. [Medline: 3506211]

40. Moritsch E, Mitschke H. [Surgical elimination of endonasal triggerpoints of a trigeminal neuralgia caused by cauterization (author's transl)]. Laryngol Rhinol Otol (Stuttg). 1977 Jan;56(1):88-90. German. [Medline: 138058]

41. Sawaya RA. Trigeminal neuralgia associated with sinusitis. ORL J Otorhinolaryngol Relat Spec. 2000 MayJun;62(3):160-3. [Medline: 10810262] [doi: 10.1159/000027738]

42. Chakraborty A, Bavetta S, Leach J, Kitchen N. Trigeminal neuralgia presenting as Chiari I malformation. Minim Invasive Neurosurg. 2003 Feb;46(1):47-9. [Medline: 12640584] [doi: 10.1055/s-2003-37959]

43. Lin YW, Lin SK, Weng IH. Fatal paranasal sinusitis presenting as trigeminal neuralgia. Headache. 2006 Jan;46(1):174-8. [Medline: 16412169] [doi: 10.1111/j.1526-4610.2006.00316_5.x] 
44. Jannetta PJ. Arterial compression of the trigeminal nerve at the pons in patients with trigeminal neuralgia. J Neurosurg. 1967 Jan;26(1):Suppl:159-62. [Medline: 6018932] [doi: 10.3171/jns.1967.26.1part2.0159]

45. Haines SJ, Jannetta PJ, Zorub DS. Microvascular relations of the trigeminal nerve. An anatomical study with clinical correlation. J Neurosurg. 1980 Mar;52(3):381-6. [Medline: 7359193] [doi: 10.3171/jns.1980.52.3.0381]

46. Jannetta PJ. Neurovascular compression in cranial nerve and systemic disease. Ann Surg. 1980;192(4):518-25. [Medline: 6968543] [doi: 10.1097/00000658-198010000-00010] [FREE Full Text]

47. Richards P, Shawdon H, Illingworth R. Operative findings on microsurgical exploration of the cerebello-pontine angle in trigeminal neuralgia. J Neurol Neurosurg Psychiatry. 1983 Dec;46(12):1098-101. [Medline: 6607319] [doi: 10.1136/jnnp.46.12.1098] [FREE Full Text]

48. Fukushima T. Microvascular decompression for hemifacial spasm and trigeminal neuralgia: results in 4000 cases. J Neurol Neurosurg Psychiatry 1990;53:173.

49. Meaney JF, Eldridge PR, Dunn LT, Nixon TE, Whitehouse GH, Miles JB. Demonstration of neurovascular compression in trigeminal neuralgia with magnetic resonance imaging. Comparison with surgical findings in 52 consecutive operative cases. J Neurosurg. 1995 Nov;83(5):799-805. [Medline: 7472546] [doi: 10.3171/jns.1995.83.5.0799]

50. Bowsher D. Trigeminal neuralgia: an anatomically oriented review. Clin Anat. 1997;10(6):409-15. Review. [Medline: 9358972] [doi: 10.1002/(SICI)1098-2353(1997)10:6<409::AID-CA7>3.0.CO;2-J]

51. Hamlyn PJ. Neurovascular relationships in the posterior cranial fossa, with special reference to trigeminal neuralgia. 2. Neurovascular compression of the trigeminal nerve in cadaveric controls and patients with trigeminal neuralgia: quantification and influence of method. Clin Anat. 1997;10(6):380-8. [Medline: 9358968] [doi: 10.1002/(SICI)1098-2353(1997)10:6<380::AID-CA2>3.0.CO;2-T]

52. McLaughlin MR, Jannetta PJ, Clyde BL, Subach BR, Comey CH, Resnick DK. Microvascular decompression of cranial nerves: lessons learned after 4400 operations. J Neurosurg. 1999 Jan;90(1):1-8. [Medline: 10413149] [doi: 10.3171/jns. 1999.90.1.0001]

53. Brock S, Scaioli V, Ferroli P, Broggi G. Neurovascular decompression in trigeminal neuralgia: role of intraoperative neurophysiological monitoring in the learning period. Stereotact Funct Neurosurg. 2004;82(5-6):199-206. Epub 2004 Nov 30. [Medline: 15583464] [doi: 10.1159/000082446]

54. de Bondt BJ, Stokroos R, Casselman J. Persistent trigeminal artery associated with trigeminal neuralgia: hypothesis of neurovascular compression. Neuroradiology. 2007 Jan;49(1):23-6. Epub 2006 Nov 7. [Medline: 17089114] [doi: $10.1007 / \mathrm{s} 00234-006-0150-8$ ]

55. Bond AE, Zada G, Gonzalez AA, Hansen C, Giannotta SL. Operative strategies for minimizing hearing loss and other major complications associated with microvascular decompression for trigeminal neuralgia. World Neurosurg. 2010 Jul;74(1):172-7. [Medline: 21300010] [doi: 10.1016/j.wneu.2010.05.001]

56. Chen J, Guo ZY, Liang QZ, Liao HY, Su WR, Chen CX, Fu SX, Han XJ. Structural abnormalities of trigeminal root with neurovascular compression revealed by high resolution diffusion tensor imaging. Asian Pac J Trop Med. 2012 Sep;5(9):749-52. [Medline: 22805730] [doi: 10.1016/S1995-7645(12)60119-9]

57. Figueiredo PC, Brock M, De Oliveira AM Júnior, Prill A. Arteriovenous malformation in the cerebellopontine angle presenting as trigeminal neuralgia. Arq Neuropsiquiatr. 1989 Mar;47(1):61-71. Review. [Medline: 2669692]

58. Ito M, Sonokawa T, Mishina H, Iizuka Y, Sato K. Dural arteriovenous malformation manifesting as tic douloureux. Surg Neurol. 1996 Apr;45(4):370-5. [Medline: $\underline{\text { 8607089] [doi: 10.1016/0090-3019(95)00438-6] }}$

59. Edwards RJ, Clarke Y, Renowden SA, Coakham HB. Trigeminal neuralgia caused by microarteriovenous malformations of the trigeminal nerve root entry zone: symptomatic relief following complete excision of the lesion with nerve root preservation. J Neurosurg. 2002 Oct;97(4):874-80. [Medline: 12405376] [doi: 10.3171/jns.2002.97.4.0874]

60. Ferroli P, Acerbi F, Broggi M, Broggi G. Arteriovenous micromalformation of the trigeminal root: intraoperative diagnosis with indocyanine green videoangiography: case report. Neurosurgery. 2010 Sep;67(3 Suppl Operative):onsE309-10; discussion onsE310. [Medline: 20679916] [doi: 10.1227/01.NEU.0000381769.15291.4C]

61. Matthies C, Samii M. Management of 1000 vestibular schwannomas (acoustic neuromas): clinical presentation. Neurosurgery. 1997 Jan;40(1):1-9; discussion 9-10. [Medline: 8971818 ]

62. Miller JP, Acar F, Burchiel KJ. Trigeminal neuralgia and vascular compression in patients with trigeminal schwannomas: case report. Neurosurgery. 2008 Apr;62(4):E974-5; discussion E975. [Medline: 18496167] [doi: 10.1227/01.neu.0000318187.10536.bf]

63. Haddad FS, Taha JM. An unusual cause for trigeminal neuralgia: contralateral meningioma of the posterior fossa. Neurosurgery. 1990 Jun;26(6):1033-8. Review. [Medline: 2194138] [doi: 10.1227/00006123-199006000-00019]

64. Ogasawara H, Oki S, Kohno H, Hibino S, Ito Y. Tentorial meningioma and painful tic convulsif. Case report. J Neurosurg. 1995 May;82(5):895-7. Review. [Medline: 7714618] [doi: 10.3171/jns.1995.82.5.0895]

65. Cheng WC, Chang CN. Trigeminal neuralgia caused by contralateral supratentorial meningioma. J Clin Neurosci. 2008 Oct;15(10):1162-3. Epub 2008 Aug 13. [Medline: 18703336] [doi: 10.1016/j.jocn.2007.05.031]

66. Kano H, Awan NR, Flannery TJ, Iyer A, Flickinger JC, Lunsford LD, Kondziolka D. Stereotactic radiosurgery for patients with trigeminal neuralgia associated with petroclival meningiomas. Stereotact Funct Neurosurg. 2011 Feb;89(1):17-24. Epub 2010 Dec 1. [Medline: 21124048] [doi: 10.1159/000321187] 
67. Jamjoom AB, Jamjoom ZA, al-Fehaily M, el-Watidy S, al-Moallem M, Nain-Ur-Rahman. Trigeminal neuralgia related to cerebellopontine angle tumors. Neurosurg Rev. 1996;19(4):237-41. [Medline: 9007886] [doi: 10.1007/BF00314838]

68. Mohanty A, Venkatrama SK, Rao BR, Chandramouli BA, Jayakumar PN, Das BS. Experience with cerebellopontine angle epidermoids. Neurosurgery. 1997 Jan;40(1):24-9; discussion 29-30. [Medline: $\underline{\text { 8971820] }}$

69. Guttal KS, Naikmasur VG, Joshi SK, Bathi RJ. Trigeminal neuralgia secondary to epidermoid cyst at the cerebellopontine angle: case report and brief overview. Odontology. 2009 Jan;97(1):54-6. Epub 2009 Jan 29. Review. [Medline: 19184299] [doi: $10.1007 / \mathrm{s} 10266-008-0088-\mathrm{x}$ ]

70. Guo Z, Ouyang H, Cheng Z. Surgical treatment of parapontine epidermoid cysts presenting with trigeminal neuralgia. J Clin Neurosci. 2011 Mar;18(3):344-6. Epub 2011 Jan 17. [Medline: 21247769] [doi: 10.1016/j.jocn.2010.07.110]

71. Borne G. Trigeminal neuralgia as the presenting symptom of a tuberculoma of the cerebellopontine angle. Case report. J Neurosurg. 1968 May;28(5):480-2. [Medline: 5301710] [doi: 10.3171/jns. 1968.28.5.0480]

72. Banerjee AK, Chopra JS. Uncommon neurological presentations of tuberculoma. Clin Neurol Neurosurg. 1979;81(2):122-8. [Medline: 225079] [doi: 10.1016/S0303-8467(79)80023-2]

73. Kato T, Sawamura Y, Abe H. Trigeminal neuralgia caused by a cerebellopontine-angle lipoma: case report. Surg Neurol. 1995 Jul;44(1):33-5. [Medline: 7482251] [doi: 10.1016/0090-3019(95)00056-9]

74. Revuelta R, Juambelz P, Balderrama J, Teixeira F. Contralateral trigeminal neuralgia: a new clinical manifestation of neurocysticercosis: case report. Neurosurgery. 1995 Jul;37(1):138-9; discussion 139-40. [Medline: 8587675] [doi: 10.1227/00006123-199507000-00022]

75. Matsuura N, Kondo A. Trigeminal neuralgia and hemifacial spasm as false localizing signs in patients with a contralateral mass of the posterior cranial fossa. Report of three cases. J Neurosurg. 1996 Jun;84(6):1067-71. [Medline: $\underline{8847575]}$ [doi: 10.3171/jns.1996.84.6.1067]

76. Nurmikko TJ, Eldridge PR. Trigeminal neuralgia--pathophysiology, diagnosis and current treatment. Br J Anaesth. 2001 Jul;87(1):117-32. [doi: 10.1093/bja/87.1.117] [FREE Full Text]

77. Moazzam AA, Habibian M. Patients appearing to dental professionals with orofacial pain arising from intracranial tumors: a literature review. Oral Surg Oral Med Oral Pathol Oral Radiol. 2012 Dec;114(6):749-55. Epub 2012 Oct 1. [Medline: 23036798] [doi: 10.1016/j.0000.2012.06.017]

78. Ildan F, Göçer AI, Bağdatoğlu H, Uzuneyüpoğlu Z, Tuna M, Cetinalp E. Isolated trigeminal neuralgia secondary to distal anterior inferior cerebellar artery aneurysm. Neurosurg Rev. 1996;19(1):43-6. [Medline: 8738365] [doi: 10.1007/BF00346609]

79. Schmerber S, Vasdev A, Chahine K, Tournaire R, Bing F. Internal carotid false aneurysm after thermocoagulation of the gasserian ganglion. Otol Neurotol. 2008 Aug;29(5):673-5. [Medline: 18580544] [doi: 10.1097/MAO.0b013e31817ef4cc]

80. Sindou M, Leston J, Decullier E, Chapuis F. Microvascular decompression for primary trigeminal neuralgia: longterm effectiveness and prognostic factors in a series of 362 consecutive patients with clear-cut neurovascular conflicts who underwent pure decompression. J Neurosurg. 2007 Dec;107(6):1144-53. [Medline: 18077952] [doi: $10.3171 / \mathrm{JNS}-07 / 12 / 1144]$

81. Brisman R, Khandji AG, Mooij RB. Trigeminal Nerve-Blood Vessel Relationship as Revealed by High-resolution Magnetic Resonance Imaging and Its Effect on Pain Relief after Gamma Knife Radiosurgery for Trigeminal Neuralgia. Neurosurgery. 2002 Jun;50(6):1261-6, discussion 1266-7. [Medline: 12015844]

82. Klun B, Prestor B. Microvascular relations of the trigeminal nerve: an anatomical study. Neurosurgery. 1986 Oct; 19(4):5359. [Medline: 3785594] [doi: 10.1227/00006123-198610000-00007]

83. Tash RR, Sze G, Leslie DR. Trigeminal neuralgia: MR imaging features. Radiology. 1989 Sep;172(3):767-70. [Medline: 2772186]

84. Majoie CB, Hulsmans FJ, Verbeeten B Jr, Castelijns JA, van Beek EJ, Valk J, Bosch DA. Trigeminal neuralgia: comparison of two MR imaging techniques in the demonstration of neurovascular contact. Radiology. 1997 Aug;204(2):455-60. [Medline: $\underline{9240535]}$

85. Meaney JF, Miles JB, Nixon TE, Whitehouse GH, Ballantyne ES, Eldridge PR. Vascular contact with the fifth cranial nerve at the pons in patients with trigeminal neuralgia: detection with 3D FISP imaging. AJR Am J Roentgenol. 1994 Dec;163(6):1447-52. [Medline: 799274] [FREE Full Text]

86. Adams CB. Trigeminal neuralgia: pathogenesis and treatment. $\mathrm{Br}$ J Neurosurg. 1997 Dec;11(6):493-5. [Medline: 11013619] [doi: 10.1080/02688699745637]

87. Sicard A. [Bernard Pierson 1925--1978]. Arch Anat Cytol Pathol. 1978;26(2):79-80. French. [Medline: 371549]

88. Hanes WJ. Tic douloureux: a new allergic approach to the etiology and treatment. A report of seventy-six cases. Ann Allergy. 1962 Oct;20:635-48. [Medline: 1395250]

89. Hanes WJ. Clinical research on the etiology and treatment of tic douloureux on an allergic basis. Report of 183 cases. Oral Surg Oral Med Oral Pathol. 1967 Jun;23(6):728-36. [Medline: 5229426] [doi: 10.1016/0030-4220(67)90361-1]

90. Dobaczewski Z. [Histamine in the treatment of trigeminal neuralgia]. Pol Tyg Lek. 1972 Jul 12;27(24):913-5. Polish. [Medline: $\underline{5040539]}$

91. Smirnov VA. [Odontologic and other etiologic factors in trigeminal neuralgia]. Zh Nevropatol Psikhiatr Im S S Korsakova. 1976;76(11):1639-42. Russian. [Medline: 1015089] 
92. Sabalis GI, Karlov VA, Morkunas RM, Stropus RA. [Peripheral mechanisms of the pathogenesis of trigeminal neuralgia] Zh Nevropatol Psikhiatr Im S S Korsakova. 1982;82(4):25-9. Russian. [Medline: 7090661]

93. Jia DZ, Li G. Bioresonance hypothesis: a new mechanism on the pathogenesis of trigeminal neuralgia. Med Hypotheses. 2010 Mar;74(3):505-7. Epub 2009 Nov 8. [Medline: 19900765] [doi: 10.1016/j.mehy.2009.09.056]

94. Devor M, Amir R, Rappaport ZH. Pathophysiology of trigeminal neuralgia: the ignition hypothesis. Clin J Pain. 2002 Jan-Feb;18(1):4-13. Review. [Medline: 11803297] [doi: 10.1097/00002508-200201000-00002]

95. Kerr FW. Correlated light and electron microscopic observations on the normal trigeminal ganglion and sensory root in man. J Neurosurg. 1967 Jan;26(1):Suppl:132-7. [Medline: 416366]

96. Kunc Z, Fuchsová M, Novák M. Excision of the spinal trigeminal tract. Electron microscopy. Acta Neurochir (Wien). 1978;41(1-3):233-41. [Medline: 665334] [doi: 10.1007/BF01809152]

97. Savas A, Deda H, Erden E, Kanpolat Y. Differential diagnosis of idiopathic inflammatory trigeminal sensory neuropathy from neuroma with a biopsy: case report. Neurosurgery. 1999 Nov;45(5):1246-9; discussion 1249-50. [Medline: 10549946] [doi: 10.1097/00006123-199911000-00053]

98. Sarlani E, Grace EG, Balciunas BA, Schwartz AH. Trigeminal neuralgia in a patient with multiple sclerosis and chronic inflammatory demyelinating polyneuropathy. J Am Dent Assoc. 2005 Apr;136(4):469-76. Review. [Medline: 15884316]

99. Lewey FH. [Pathologic anatomy and physiology of trigeminal neuralgia]. Arch Psychiatr Nervenkr Z Gesamte Neurol Psychiatr. 1950;185(6-7):627-39. Undetermined Language. [Medline: 14800363] [doi: 10.1007/BF00935514]

100. Rappaport ZH, Devor M. Trigeminal neuralgia: the role of self-sustaining discharge in the trigeminal ganglion. Pain. 1994 Feb;56(2):127-38. Review. [Medline: 8008402] [doi: 10.1016/0304-3959(94)90086-8]

101.Smirnov VA. [Etiology and pathogenesis of trigeminal neuralgia]. Klin Med (Mosk). 1972 Jan;50(1):95-9. Russian. [Medline: $\underline{\text { 5020037] }}$

102. Benoist JM, Gautron M, Guilbaud G. Experimental model of trigeminal pain in the rat by constriction of one infraorbital nerve: changes in neuronal activities in the somatosensory cortices corresponding to the infraorbital nerve. Exp Brain Res. 1999 Jun;126(3):383-98. [Medline: 10382623] [doi: 10.1007/s002210050745]

103.Dott NM. Facial pain. Proceedings of the Royal Society of Medicine; 1951;44. p. 1034.

104.List CF, williams JR. Pathogenesis of trigeminal neuralgia; a review. AMA Arch Neurol Psychiatry. 1957 Jan;77(1):36-43. [Medline: 13381215$]$

105. Bogolepov NK. [An attack of typical trigeminal neuralgia as a typical multineuronal reflex]. Zh Nevropatol Psikhiatr Im S S Korsakova. 1969;69(4):487-93. Russian. [Medline: 5796662]

106.Lipshits RU, Klimenko NA. [Mast cell reaction outside the acute inflammation focus]. Arkh Patol. 1980;42(3):51-4. Russian. [Medline: 7378000]

107. Chakravarty N. Histamine release from mast cell granules. Agents Actions. 1982 Apr;12(1-2):94-8. [Medline: 6177224] [doi: 10.1007/BF01965114]

108. Orlov SM, Shustova VI. [Histamine liberation test in the diagnosis of pollenosis]. Klin Med (Mosk). 1980 Jan;58(1):8891. Russian. [Medline: 6154172 ]

109. White JR, Pearce FL. Effect of anti-allergic compounds on anaphylactic histamine secretion from rat peritoneal mast cells in the presence and absence of exogenous calcium. Immunology. 1982 Jun;46(2):361-7. [Medline: 6177625] [FREE Full Text]

110. Sterk AR, Ishizaka T. Binding properties of IgE receptors on normal mouse mast cells. J Immunol. 1982 Feb;128(2):838-43. [Medline: 7054296]

111. Chen XJ, Enerbäck L. Regulation of IgE-receptor expression, IgE occupancy and secretory capacity of mast cells. APMIS. 2000 Oct;108(10):633-41. Review. [Medline: 11200817] [doi: 10.1034/j.1600-0463.2000.d01-9.x]

112. Miecznik B. Mast cells in the cytology of nasal mucosa; a quantitative and morphologic assessment and their diagnostic meaning. Ann Allergy. 1980 Feb;44(2):106-11. [Medline: 7362082]

113. Kaliner M, Wasserman SI, Austen KF. Immunologic release of chemical mediators from human nasal polyps. N Engl J Med. 1973 Aug 9;289(6):277-81. [Medline: 4123994] [doi: 10.1056/NEJM197308092890601]

114. Iuodzhbalis GIu, Sabalis GI. [The immune status of patients with trigeminal neuralgia and its correction]. Stomatologiia (Mosk). 1989 May-Jun;68(3):44-6. Russian. [Medline: 2772940]

115. Smith FM, Haskelberg H, Tracey DJ, Moalem-Taylor G. Role of histamine H3 and H4 receptors in mechanical hyperalgesia following peripheral nerve injury. Neuroimmunomodulation. 2007;14(6):317-25. Epub 2008 Apr 10. [Medline: 18401194] [doi: 10.1159/000125048]

116. Rasminsky M. Ectopic generation of impulses and cross-talk in spinal nerve roots of "dystrophic" mice. Ann Neurol. 1978 Apr;3(4):351-7. [Medline: 208454] [doi: 10.1002/ana.410030413]

117. Smith KJ, McDonald WI. Spontaneous and evoked electrical discharges from a central demyelinating lesion. J Neurol Sci. 1982 Jul;55(1):39-47. [Medline: 6286890] [doi: 10.1016/0022-510X(82)90168-X]

118. Karlov VA. [Principal features of the pathogenesis and pathogenetic treatment of certain neurologic syndromes of the facial region]. Zh Nevropatol Psikhiatr Im S S Korsakova. 1980;80(5):676-9. Russian. [Medline: 7415687] 


\section{To cite this article:}

Sabalys G, Juodzbalys G, Wang HL. Aetiology and Pathogenesis of Trigeminal Neuralgia: a Comprehensive Review.

J Oral Maxillofac Res 2012;3(4):e2

URL: http://www.ejomr.org/JOMR/archives/2012/4/e2/v3n4e2ht.pdf

doi: $10.5037 /$ jomr.2012.3402

Copyright $@$ Sabalys G, Juodzbalys G, Wang HL. Accepted for publication in the JOURNAL OF ORAL \& MAXILLOFACIAL RESEARCH (http://www.ejomr.org), 29 December 2012.

This is an open-access article, first published in the JOURNAL OF ORAL \& MAXILLOFACIAL RESEARCH, distributed under the terms of the Creative Commons Attribution-Noncommercial-No Derivative Works 3.0 Unported License, which permits unrestricted non-commercial use, distribution, and reproduction in any medium, provided the original work and is properly cited. The copyright, license information and link to the original publication on (http://www.ejomr.org) must be included. 